\title{
Parametric Analysis of a Differential Photoacoustic Helmholtz Cell
}

\author{
Antonina Geras · Tomasz Starecki
}

Received: 19 November 2013 / Accepted: 6 March 2014 / Published online: 28 March 2014 C The Author(s) 2014. This article is published with open access at Springerlink.com

\begin{abstract}
The paper describes how mechanical dimensions of a differential open photoacoustic Helmholtz cell affect its operation. The influence of the diameter and length of the internal and external ducts and the volume of the acoustic buffers on the frequency response of the cell, as well as on the attenuation of the external acoustic noise, was studied. The analysis was performed by means of computer simulations based on a model in which loss-corrected transmission line duct definitions were used. The results showed that under proper selection of the cell dimensions, its frequency response at the frequencies around the main resonance is nearly identical as in the case of the conventional, closed Helmholtz resonator. The length of the ducts is only slightly related to the frequency of resonance, and does not noticeably affect the Qfactor of the cell. A decrease of the duct diameters and an increase of the buffer volumes improve attenuation of the external acoustic noise. It should be possible to obtain external acoustic noise rejection as high as $80 \mathrm{~dB}$, which is a substantial improvement in comparison to the previous designs, which reported this value at the level of $40 \mathrm{~dB}$ to $50 \mathrm{~dB}$.
\end{abstract}

Keywords Differential detection - External acoustic noise attenuation · Helmholtz resonator $\cdot$ Resonant photoacoustic cell

\section{Introduction}

Photoacoustic spectroscopy (PAS) is a technique commonly used for continuous flow measurements [1-7]. One of the most important components of any PAS setup is the photoacoustic cell. From the point of view of practical applications, closed photoa-

\footnotetext{
A. Geras · T. Starecki $(\bowtie)$

Institute of Electronic Systems, Warsaw University of Technology,

Nowowiejska 15/19, 00-665 Warsaw, Poland

e-mail: t.starecki@ise.pw.edu.pl; tomasz@starecki.com
} 
coustic cells are not very convenient, because they require gas sampling. In order to sample the gas, additional mechanical elements (e.g., valves) are needed, which makes the whole setup much more complex, especially if it is to be used in automated measurement systems [6]. Open cells presented in the literature [8-11] are susceptible to external acoustic noise penetration, which can seriously limit the sensitivity of the photoacoustic instrument [5]. Solving this problem may allow for wider use of this kind of photoacoustic cells in continuous flow measurements [7,12-14]. So far, the best values of the external acoustic noise suppression obtained in such cells were reported at a level of approximately $40 \mathrm{~dB}$ to $50 \mathrm{~dB}[15,16]$. A new design of an open Helmholtz cell with differential detection shown in Fig. 1 allows for substantial improvement of the external acoustic noise rejection [17].

In the proposed cell structure (Fig. 1), both cavities of a conventional Helmholtz resonator are equipped with microphones and are connected with the exterior via duct-buffer-duct structures. The length and diameter of the ducts and the volume of the acoustic buffers are selected in such a way that the acoustic impedance of the duct-buffer-duct structure observed at both ends at the frequency of light modulation is relatively high. As a result, pressure changes induced by the photoacoustic phenomenon inside the cell are not damped, while penetration of the external acoustic noise inside the cell is reduced.

Additional rejection of the external acoustic noise is obtained by differential detection. Differential detection is well known for its strong noise attenuation properties $[13,18,19]$. The cell design is symmetrical in order to obtain nearly identical penetration of the external acoustic noise into both cavities. Hence, subtraction of the signals from both cavities should virtually cancel the external acoustic noise signal components, while doubling the photoacoustic signal component, as in the Helmholtz cell working at the resonance frequency, pressure changes in the cavities are in counterphase $[13,14,20]$.

\section{Modeling Method}

It was assumed that preliminary investigation of the cell properties will be done by means of computer simulations. First, a model of the cell was created (Fig. 2). The model was based on acousto-electrical analogies, in which cavities of the cell are represented by capacitors, while properties of the ducts are described by transmission lines converted into corresponding T-section impedances. The exterior can be considered as a cavity of a very high volume; thus, it is also modeled by a capacitance (to simplify calculations, two capacitances were used: $C_{\mathrm{AL}}$ and $C_{\mathrm{AR}}$ ). Voltage sources $U_{\mathrm{AL}}$ and $U_{\mathrm{AR}}$ stand for external acoustic noise sources, while current sources $I_{1}$ and $I_{2}$ model light stimulation [14,21-24]. Pressure changes in the microphone cavities are reflected by voltage signals $U_{\mathrm{M} 1}$ and $U_{\mathrm{M} 2}$. Similar models were already used in previous studies, and they were proven to give results very close to the measurements $[2,9,14,23]$, so they can be considered as a reliable source of information on the real cell behavior.

In the discussed model, the frequency response of the cell with differential detection is expressed by the amplitude of the differential signal $\left(U_{\mathrm{M} 1}-U_{\mathrm{M} 2}\right)$ versus 
(a)

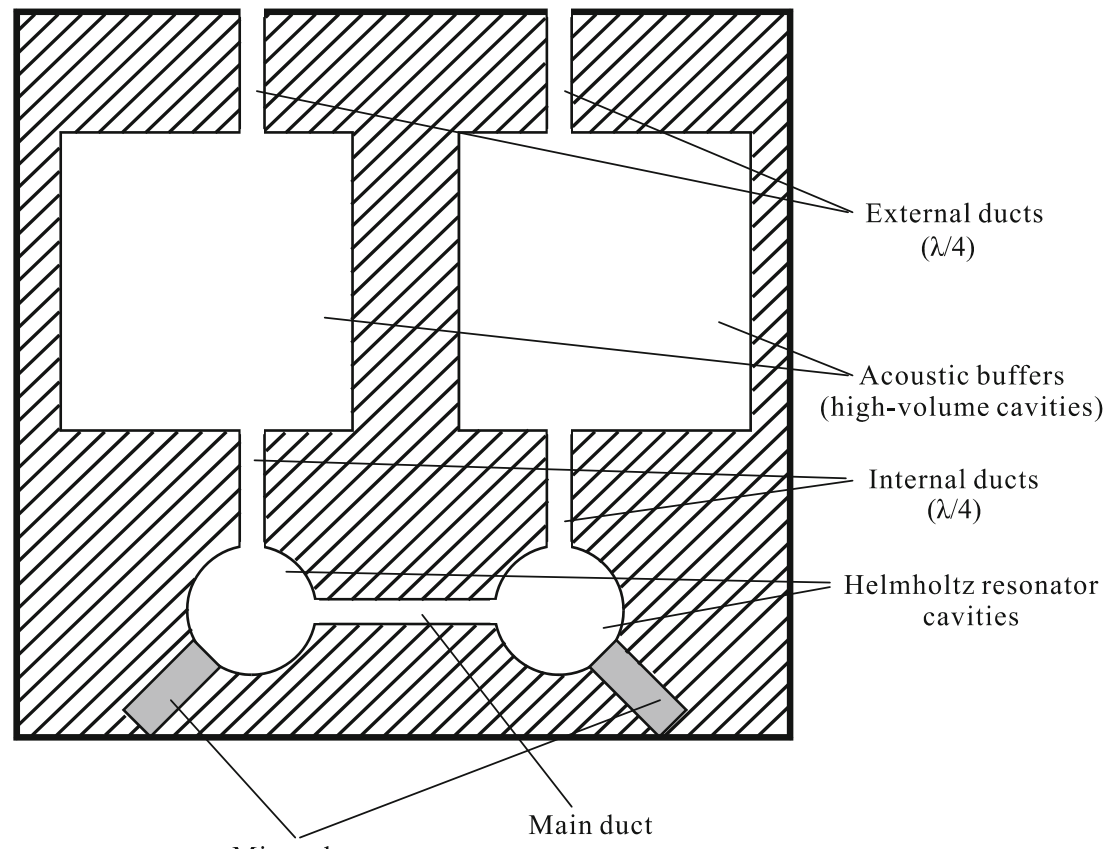

Microphones

(b)

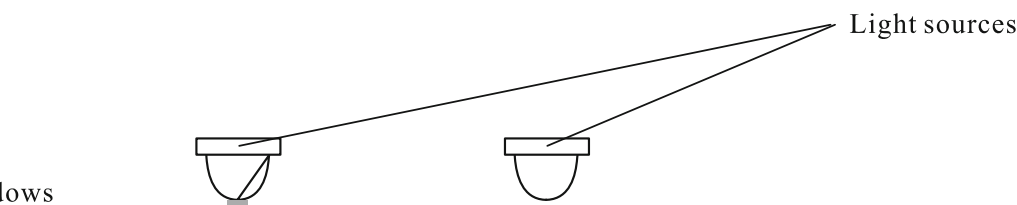

Windows

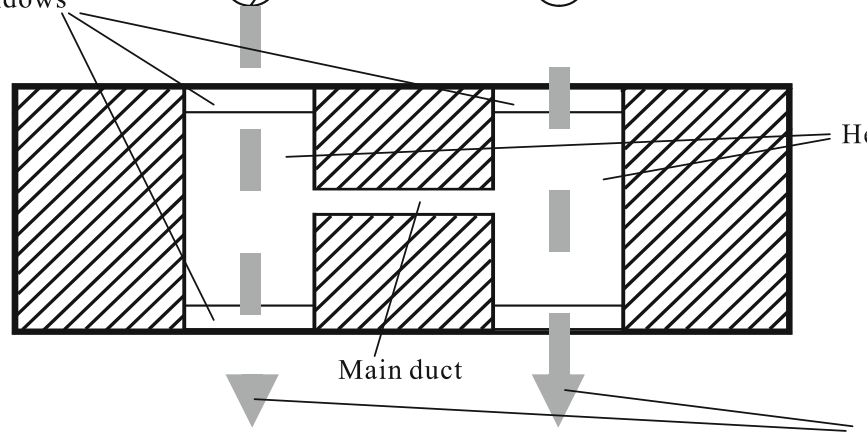

Modulated

light beams

Fig. 1 Open photoacoustic Helmholtz cell with differential detection: (a) horizontal cross section and (b) vertical cross section

frequency. For the purpose of comparison with a corresponding closed Helmholtz cell and previous photoacoustic open Helmholtz cell designs [9,11], which do not use differential detection, just one of the microphone signals can be used (e.g., $U_{\mathrm{M} 1}$ versus frequency - under the assumption that the photoacoustic signal is induced in the other cavity). Taking into consideration that differential detection should theoretically 


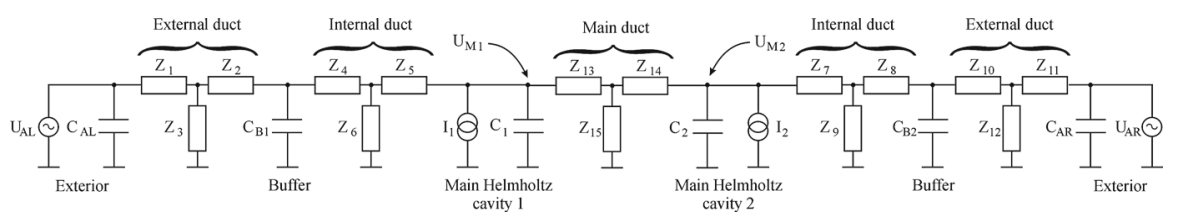

Fig. 2 Model used for determination of the properties of the differential open photoacoustic Helmholtz cell

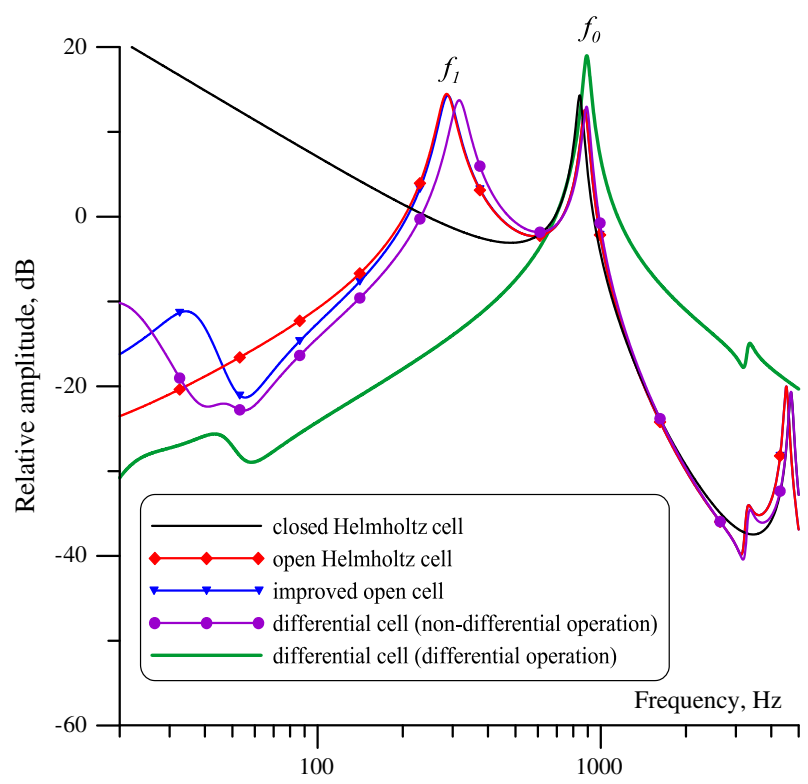

Fig. 3 Comparison of the frequency responses of different designs of the open photoacoustic Helmholtz cells and corresponding closed Helmholtz cell $[9,11,17]$

reduce external noise to zero, the noise characteristics studied in the paper describe inherent noise suppression properties of the cell, without differential detection (i.e., the plots show the relative amplitude of the external acoustic noise which would be measured with a single microphone placed in only one of the cavities). Hence, the external acoustic noise penetration level is equal to the $U_{\mathrm{M} 1} / U_{\mathrm{AL}}$ ratio (where $U_{\mathrm{M} 1}$ is calculated as a superposition of the noise signals coming from the two mentioned noise voltage sources, $U_{\mathrm{AL}}=U_{\mathrm{AR}}$ ).

Preliminary results of the simulations showing the frequency response of the cell (Fig. 3), and its noise suppression (Fig. 4) were very promising. It is clearly visible that the resonance properties of the cell are similar to the previous open Helmholtz cell designs, while its noise rejection properties are much better.

\section{Results and Discussion}

Obviously, the geometry of the cell strongly affects its frequency response and external noise infiltration inside the cell. The aim of this research was to determine the influence 


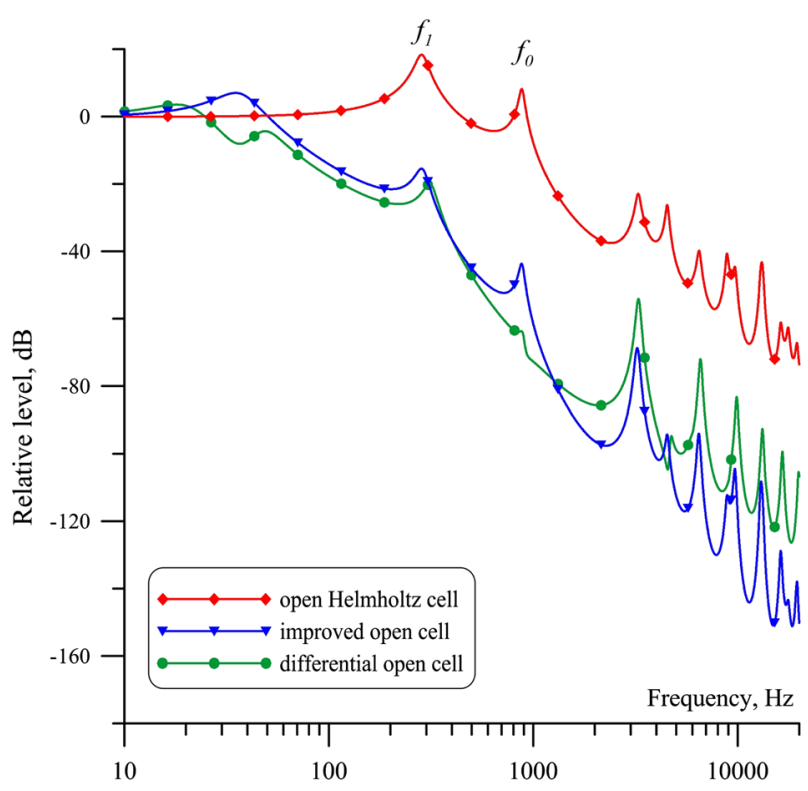

Fig. 4 Comparison of the external acoustic noise infiltration in the open photoacoustic Helmholtz cells $[9,11,17]$

of the dimensions of the cell (lengths and diameters of the ducts and volumes of the buffers) on the frequency response and external acoustic noise suppression. Searching for optimal dimensions of the cell components was performed by means of computer simulations. At each iteration, only one dimension was changed and the frequency response and noise attenuation properties were examined. The remaining parameters were the same as in the reference cell (cavity volumes- $1.5 \mathrm{~cm}^{3}$, buffer volumes$100 \mathrm{~cm}^{3}$, internal and external ducts were $50 \mathrm{~mm}$ long and $2 \mathrm{~mm}$ in diameter). The results are discussed below.

A change of the internal duct length influences the frequency response of the cell (Fig. 5a). In the case of the shortest considered duct $(25 \mathrm{~mm})$, the resonant peak occurs at about $830 \mathrm{~Hz}$, while for the longest analyzed duct $(150 \mathrm{~mm})$ - at about $700 \mathrm{~Hz}$. The Q-factor of the cell seems not to be noticeably affected by a change of the internal duct length. The resonant peak closest to the one of the closed cell is reached with the internal duct of $100 \mathrm{~mm}$. Disturbances of the frequency response visible at the frequencies above resonance should not affect acoustic amplification of the photoacoustic signal, as they are too far away from the resonance. However, they may seriously affect external acoustic noise suppression, which is clearly visible for the internal ducts longer than $100 \mathrm{~mm}$. There exists an optimal value for which further elongation of the duct does not result in an improvement of the noise attenuation and even makes it weaker (Fig. 5b). The internal duct diameter has a relatively weak influence on the frequency response in the frequency range around the main resonance of the cell (Fig. 6a). An increase of the diameter of the internal ducts causes the resonance peak to shift slightly to the direction of higher frequencies. It results also in stronger peaking of the frequency response at the harmonics of the resonance frequency, but 

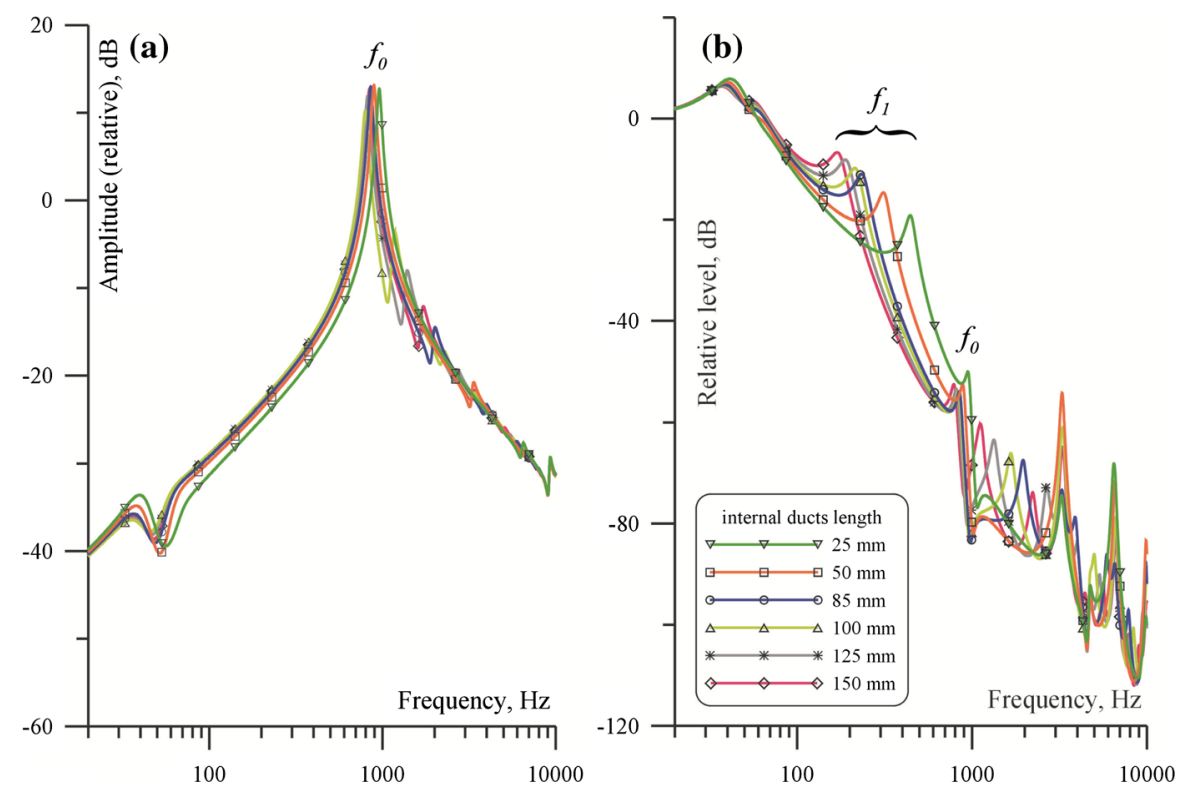

Fig. 5 Influence of the length of internal ducts on (a) frequency response and (b) external acoustic noise infiltration of the cell

this may be considered as negligible when it is assumed that the cell will be operated at the fundamental resonance frequency. As it was easy to predict, the best rejection of the external noise infiltration (Fig. 6b) is obtained when the smallest value $(1 \mathrm{~mm})$ of the duct diameter is employed. Change of the internal duct diameter from $3 \mathrm{~mm}$ down to $1 \mathrm{~mm}$ increases the external acoustic noise rejection by approximately $20 \mathrm{~dB}$ to the value of about $75 \mathrm{~dB}$. It should be noticed that this value substantially drops at the harmonics of the resonance frequency, resulting in a much worse signal-to-noise ratio at these frequencies.

From Fig. 7a it is clearly visible that no matter what the external duct length is, the frequency response around the resonant peak and at higher frequencies remains unchanged. The only noticeable changes of the frequency response occur at the frequencies approximately ten times lower than the main resonance frequency of the cell. On the other hand, the length of the external ducts noticeably affects external acoustic noise infiltration (Fig. 7b). Its elongation helps to reject the external noise. However, similarly as in the case of the internal duct, there is an optimal value for which further elongation causes the attenuation to weaken. It seems that the best results should be obtained with an external duct of $85 \mathrm{~mm}$ to $100 \mathrm{~mm}$ in length.

Likewise in the case of the internal duct length, the frequency response of the investigated cell is nearly not affected by the changes of the diameter of the external ducts (Fig. 8a). However, this dimension has a strong impact on the external noise attenuation (Fig. 8b). A reduction of the internal duct diameter from $3 \mathrm{~mm}$ to $1 \mathrm{~mm}$ improves the attenuation by about $20 \mathrm{~dB}$. 

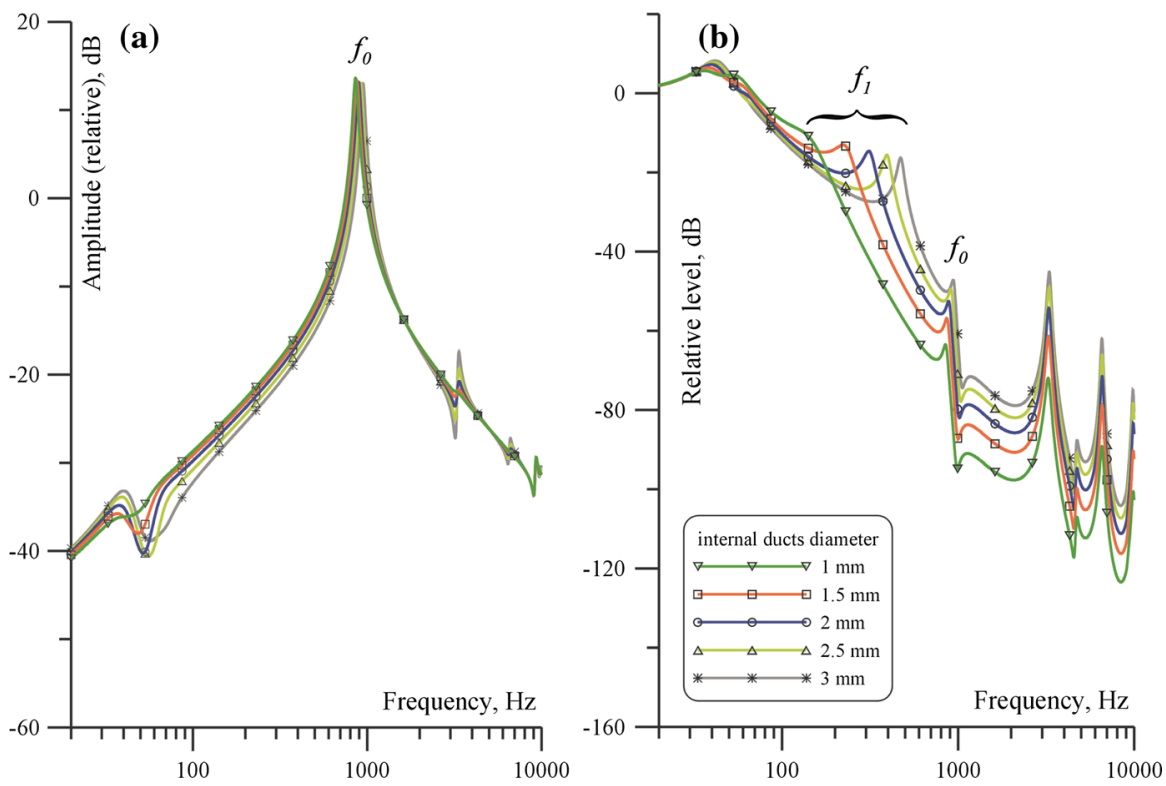

Fig. 6 Influence of the diameter of internal ducts on (a) frequency response and (b) external acoustic noise infiltration of the cell
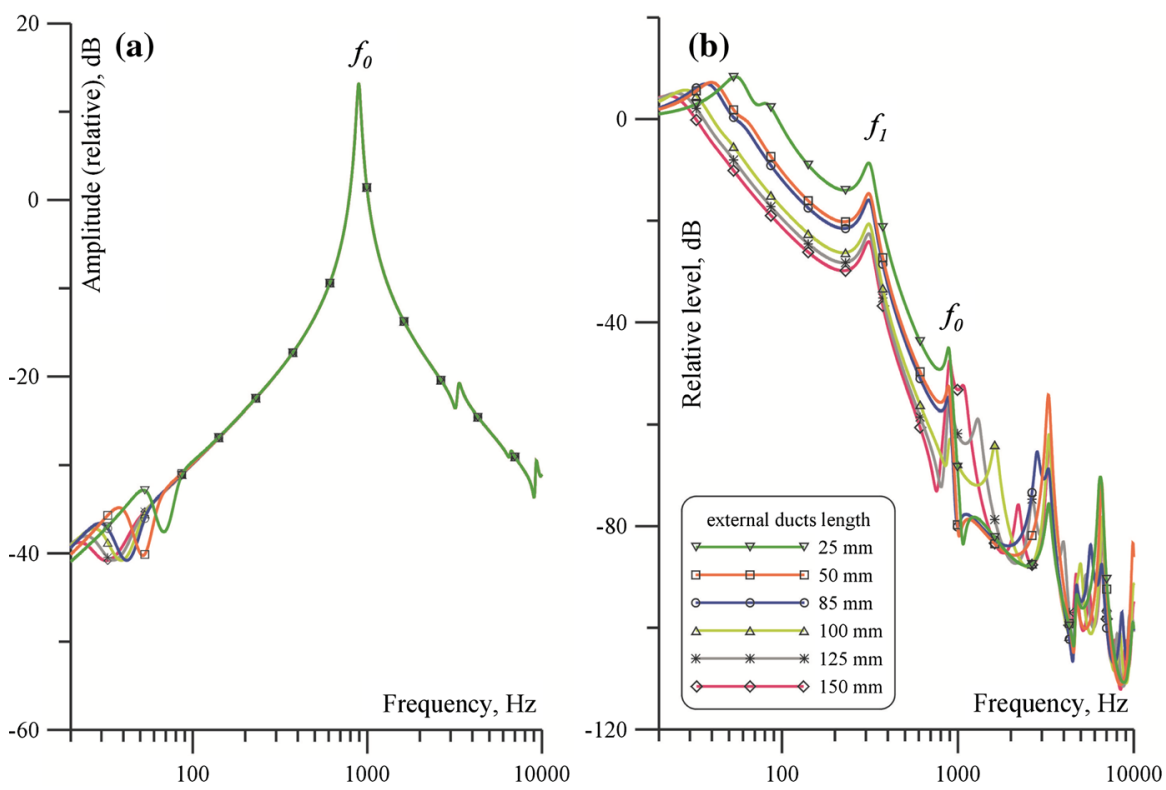

Fig. 7 Influence of the length of external ducts on (a) frequency response and (b) external acoustic noise infiltration of the cell

A change of the buffer volumes affects noticeably the frequency response only in the range of relatively low frequencies (Fig. 9a). More important is its influence on the external noise attenuation, which can be substantially improved by increasing the 

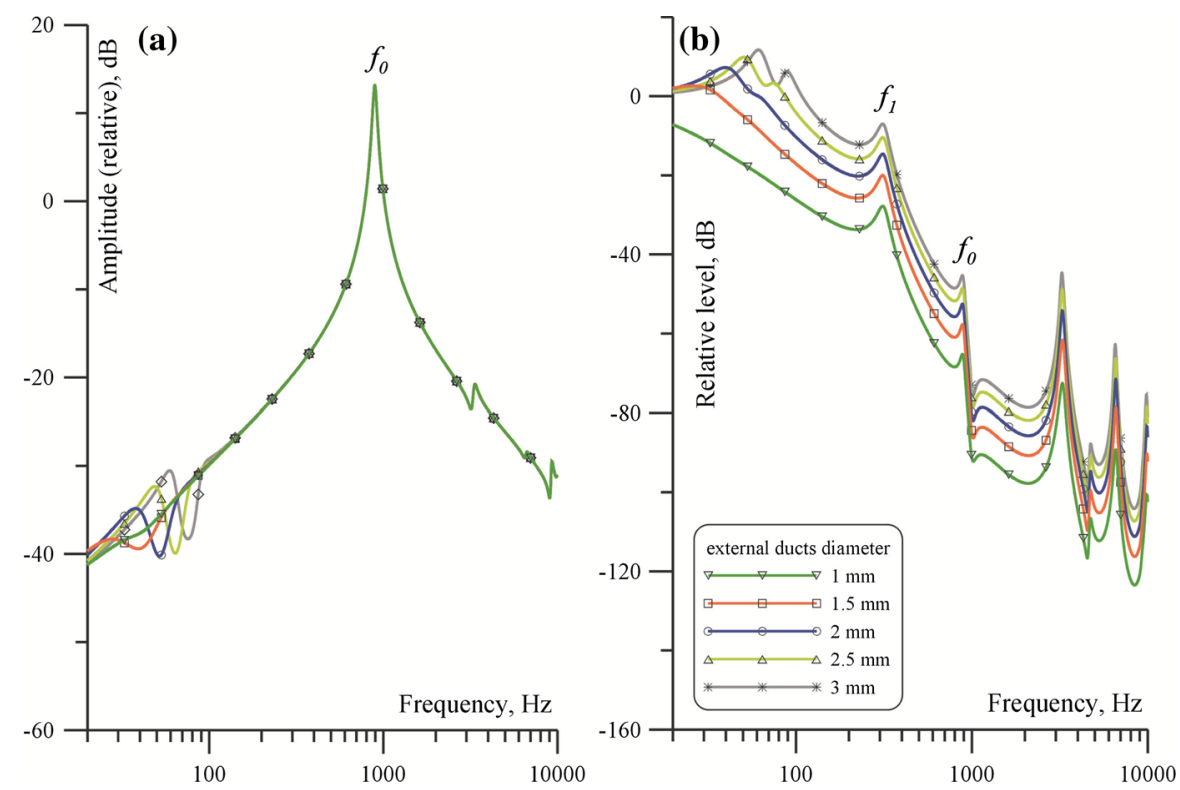

Fig. 8 Influence of the diameter of external ducts on (a) frequency response and (b) external acoustic noise infiltration of the cell
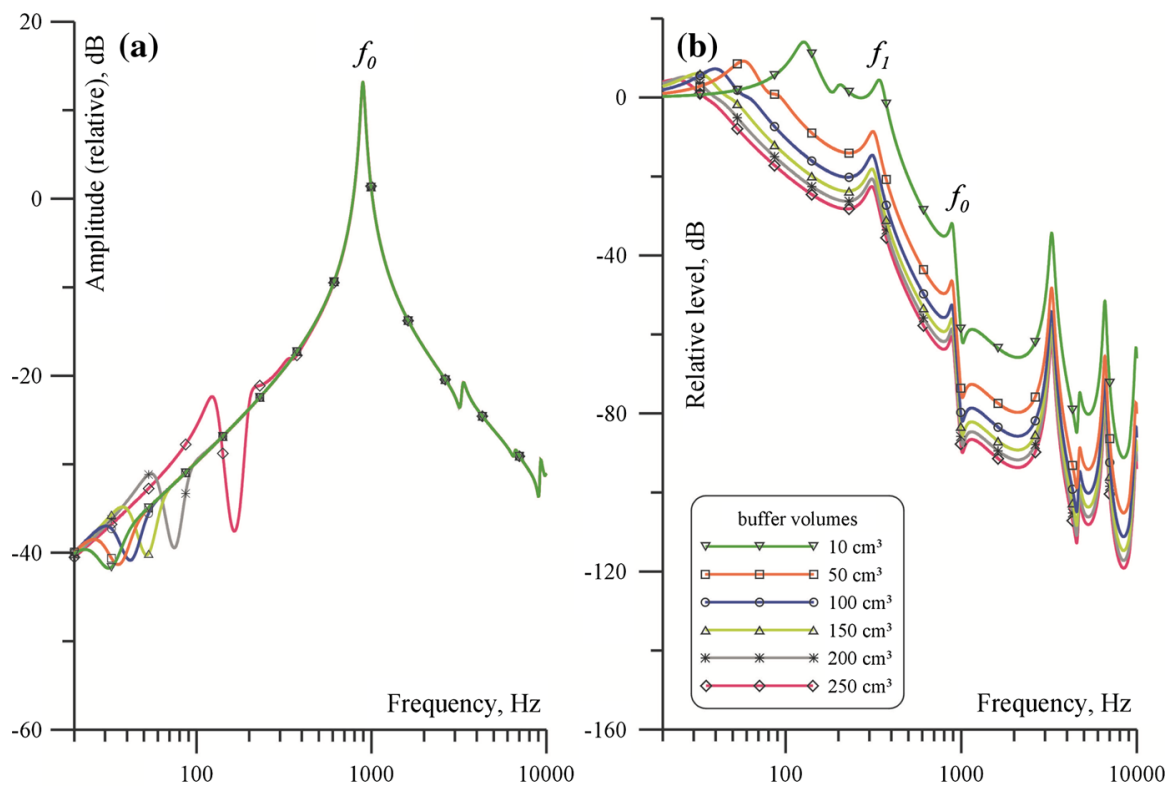

Fig. 9 Influence of the buffer volumes on (a) frequency response and (b) external acoustic noise infiltration of the cell

volume of the buffers (Fig. 9b). The size of the buffers is limited only by practical conditions, as they contribute to the total size of the cell, which usually should be kept rather small. 


\section{Conclusions}

The presented parametric analysis showed that the frequency response of the investigated open photoacoustic Helmholtz cell structure is relatively insensitive to adjustment of the selected cell dimensions (length and diameter of internal and external ducts, volume of the buffer cavities). A noticeable shift of the resonance frequency $f_{0}$ can be observed only in the case of internal duct length or diameter changes. None of the investigated dimension changes seems to seriously affect the Q-factor of the cell. Use of differential detection results in efficient rejection of the signals for which the frequencies are away from the main resonance of the cell. At one octave from $f_{0}$, the attenuation is at the level of approximately $30 \mathrm{~dB}$.

External acoustic noise suppression can be improved by a few tens of decibels by proper selection of the cell dimensions. In the case of both internal and external ducts, smaller diameters help to prevent infiltration of the external acoustic noise into the cell. Similarly, an increase of the buffer volumes improves attenuation of the noise. Finding the optimal lengths of the internal and external ducts is not straightforward. In both cases the most efficient noise rejection is obtained at some intermediate length values. Under an optimal choice of the cell dimensions, it should be possible to get external acoustic noise rejection as high as $70 \mathrm{~dB}$ to $80 \mathrm{~dB}$, which is a substantial improvement over previous open Helmholtz cell designs, which reported this value at the level of $40 \mathrm{~dB}$ to $50 \mathrm{~dB}$. The above value describes the inherent external acoustic noise suppression properties of the cell. Use of differential detection should still improve the noise rejection.

Open Access This article is distributed under the terms of the Creative Commons Attribution License which permits any use, distribution, and reproduction in any medium, provided the original author(s) and the source are credited.

\section{References}

1. D.H. McQueen, J. Phys. E 16, 738 (1983)

2. M.D. da Silva, I.N. Bandeira, L.C.M. Miranda, J. Phys. E 20, 1476 (1987)

3. J.A. Balderas-López, A. Mandelis, J. Appl. Phys. 90, 2273 (2001)

4. A. Keller, M. Rüegg, M. Forster, M. Loepfe, R. Pleisch, P. Nebiker, H. Burtscher, Sens. Actuators B 104, 1 (2005)

5. Z. Bozóki, A. Szabó, Á. Mohácsi, G. Szabó, Sens. Actuators B 147, 206 (2010)

6. K. Keränen, K. Kautio, J. Ollila, M. Heikkinen, I. Kauppinen, T. Kuusela, B. Matveev, M.E. McNie, R.M. Jenkins, P. Karoioja, Proc. SPIE 7606, 760614 (2010)

7. J. Uotila, V. Koskinen, J. Kauppinen, Vib. Spectrosc. 38, 3 (2005)

8. T. Diószeghy, A. Miklós, A. Kelemen, A. Lőrincz, J. Appl. Phys. 58, 2105 (1985)

9. T. Starecki, Acta Phys. Pol. A 114, A211 (2008)

10. T. Starecki, Acta Phys. Pol. A 114, A199 (2008)

11. T. Starecki, A. Geras, Int. J. Thermophys. (2013). doi:10.1007/s10765-013-1479-y

12. A. Miklós, A.H. Kung, P. Hess, Proc. SPIE 4817, 96 (2002)

13. K. Song, H.K. Cha, V.A. Kapitanov, YuN Ponomarev, A.P. Rostov, D. Courtois, B. Parvitte, V. Zeninari, Appl. Phys. B 75, 215 (2002)

14. V. Zeninari, V.A. Kapitanov, D. Courtois, Infrared Phys. Technol. 40, 1 (1999)

15. A. Miklós, A. Lőrincz, Appl. Phys. B 48, 213 (1989)

16. A. Geras, T. Starecki, Int. J. Thermophys. (2013). doi:10.1007/s10765-013-1497-9 
17. T. Starecki, A. Geras, Int. J. Thermophys. (2014). doi:10.1007/s10765-014-1570-z

18. D. Cahen, E.I. Lerner, A. Auerbach, Rev. Sci. Instrum. 49, 1206 (1978)

19. A. Rosencwaig, Photoacoustics and Photoacoustic Spectroscopy (Wiley, New York, 1980)

20. H.S. Lee, D.D. Lee, Appl. Opt. 27, 1 (1988)

21. T. Starecki, Electron. Telecommun. Q. 39, 307 (1993)

22. M. Suchenek, Proc. SPIE 6937, 693711 (2007)

23. T. Starecki, J. Acoust. Soc. Am. 122, 2118 (2007)

24. T. Starecki, Proc. SPIE 6159, 61592M-1-4 (2006) 